\title{
Regional Differentiation and National Uniformity: Norwegian Elementary School Legislation in the Eighteenth and Early Nineteenth Century
}

\author{
Tone Skinningsrud \\ Randi Skjelmo
}

\begin{abstract}
Previous research on Norwegian educational reforms after 1814, the year when Norway became a constitutional state, has emphasized the conservatism of the elementary education acts of 1816 and 1827. Contrary to expectations for a constitutional state, these acts did not reflect a concern for fostering politically active citizens. Neither did they follow up the enlightenment idea of teaching secular knowledge to the common people. We raise a new question concerning post-1814 educational legislation in Norway: was there an increased emphasis on national uniformity after 1814 ? A close reading of the earlier 1739/41 acts and the 1827 act, including the Plan and Instruction from 1834, studies of the debates in the Norwegian Parliament 1815-1827 and the temporary 1816 act on elementary education, show that policy after 1814 emphasised national uniformity more than before. Despite continued local funding of elementary schooling, national policy and legislation promoted uniformity.
\end{abstract}

Keywords • eighteenth and nineteenth century elementary education, citizenship education, eighteenth and nineteenth century educational legislation, history of Norwegian education, compulsory schooling, educational uniformity, educational unification

\section{Introduction: Regional diversity and national uniformity}

Historians have called the period from 1789 to 1848 in European and American history "the Age of Revolutions". In European countries, enlightenment inspired political movements brought absolute monarchy to an end. The French and American revolutions inspired the drafting of constitutions as well as a series of other reforms based on enlightenment ideas, including educational reforms. ${ }^{2}$ The Scandinavian countries were a part of this wave, although each country adopted their modern constitution at different times. Sweden adopted a constitution in 1809, Norway in 1814, Denmark in 1848, and Finland in 1919. The Norwegian 1814-constitution

1 Eric Hobsbawm, The Age of Revolution 1789-1848. 1st Vintage Books Ed. (New York: Random House, 1996 [1962]).

2 Johannes Westberg, "En politisk illusion? 1842 års folkskolestadga och den svenska folkskolan," Uddannelseshistorie 48 (2014), 52-70; Merja Paksuniemi, "Udvikling af det finske folkeskolevæsen fra 1860'erne til 1920'erne," Uddannelseshistorie 48 (2014), 71-82; Tone Skinningsrud and Randi Skjelmo, "Fra enevelde til konstitusjonell stat: Forutsetninger for allmueskolelovgivning i Norge etter 1814," Uddannelseshistorie 48 (2014), 31-51.

Tone Skinningsrud is Professor of Education at the Department of Education, University of Tromsø, The Arctic University of Norway.

Email: tone.skinningsrud@uit.no

Randi Skjelmo is Associate Professor of Education at the Department of Education, University of Tromsø, The Arctic University of Norway.

Email: randi.skjelmo@uit.no

Nordic Journal of Educational History 2016. ( ) Tone Skinningsrud and Randi Skjelmo. This is an Open Access article distributed under the terms of the Creative Commons CC-BY4.0 License (http://creativecommons.org/licenses/by/4.0/). 
was established in the immediate aftermath of the Napoleonic wars, where Denmark-Norway, which was then in a union, had been on the losing side. As part of the Kiel Peace Treaty, the Danish king seceded Norway to Sweden. However, in this process, an assembly of leading members of Norwegian society worked out a constitution, which the Swedish king accepted with minor modifications. In this "Age of Revolutions", political and social development in Scandinavia showed a "[...] remarkable continuity with the past. The monarchies and the state churches were never seriously challenged [...]."3

Recent contributions to comparative curriculum history have explored the connection between the introduction of constitutions and educational reforms, pointing to the affinity between constitutional conceptions of citizens and citizenship, and educational reforms seeking to implement citizenship education. In France, which is an exceptional case, in the late eighteenth and early nineteenth century, each constitutional reform in a long series of reforms was followed by an educational reform. ${ }^{4}$ As Daniel Tröhler points out, among the Scandinavian countries, Denmark does not conform to this pattern. Norway, on the other hand, followed the "continental pattern" of first introducing a constitution and then implementing educational reforms that promoted compulsory schooling. In this article we will examine more closely the case of Norway, and the nature of the educational reforms that followed the introduction of the 1814-constitution.

Already in 1814, Denmark introduced education acts whose explicit official mission was to create useful citizens. This was several decades before the country adopted a modern constitution. ${ }^{5}$ The expressed purpose of the 1814 Danish rural elementary education act was twofold: bringing up children in the Lutheran faith and creating useful citizens for the state. ${ }^{6}$ Creating useful citizens entailed the fostering of "citizenship virtues" and the transmission of knowledge and skills of a secular nature. ${ }^{7}$ These objectives represented a follow-up of enlightenment ideas that had been widely discussed in the decades preceding the Danish educational reform. A wide range of secular school subjects had been suggested as relevant for the peasant population - among others, astronomy. The Danish notion of useful citizens in the 1814 acts tied up with the ideal of patriotism, which was a strong movement in Denmark towards the end of the eighteenth century, especially among the bourgeoisie. Patriotism meant loyalty and willingness to serve the state rather than participating in the state. ${ }^{8}$

Education for citizenship is a highly relevant perspective for the analysis of educational reforms at the beginning of the nineteenth century. Previous research

3 Pasi Ihalainen, Michael Bregnsbo and Karin Sennefelt, eds., Scandinavia in the Age of Revolutions: Nordic Political Cultures 1789-1848 (Farnham: Ashgate Publishing Groups, 2011), 1.

4 Daniel Tröhler, "Curriculum History," in The Oxford Handbook for the History of Education (2016, in press)

5 In the recently published Danish History of Education (volume 2) chapter 7 is devoted to "The education acts of 1814". The five acts were about elementary education in a) rural areas in Denmark, b) in Copenhagen, c) in the towns, d) in Slesvig-Holstein and f) for the Jewish population; Christian Larsen, Erik Nørr, and Pernille Sonne, Da skolen tog form 1780-1850, Dansk skolehistorie, vol. 2 (Aarhus: Aarhus Universitetsforlag, 2013).

6 Anordning for almueskolevesenet paa Landet i Danmark, 29 July, 1814, Introduction.

7 Ibid. Introduction and $\$ 22$

8 Larsen, Nørr, and Sonne (2013), 53-54. 
on Norwegian educational legislation following the establishment of Norway as a constitutional state has addressed this issue and has drawn attention to the lack of concern for citizenship education in Norwegian post-constitution education laws. In this article, we have shifted the focus. We want to highlight another theme that figured in the educational debates and legislative practice at this time, namely regional differentiation and national uniformity. Previous analyses of the Norwegian 1827 elementary education act and the debates leading up to the act have not drawn attention to this aspect of educational policy. Recently, however, in connection with the celebration of the 200 years anniversary of the 1814 Norwegian constitution, Norwegian historians have claimed that 1814 marked a shift in policy for the Norwegian realm. Before 1814 the policy pursued by the Danish absolute king promoted regional differentiation, while after 1814, when Norway had become a constitutional state, differential treatment of the regions was largely abandoned, and a policy of national uniformity was pursued. ${ }^{9}$ In this article, we raise the following question: did 1814 mark a change in educational policy and legislation, from differential treatment of the regions to the more consistent promotion of national uniformity?

In choosing our research focus, the recently published new history of Danish education, which has drawn attention to various dimension of educational diversity, among them regional variations, has been a source of inspiration. The Danish project explicitly challenges the established narrative of Danish education as the history of "the school" in the singular, ignoring the great variety of schools that existed simultaneously through all stages of history. ${ }^{10}$

Also the work of the British sociologist Margaret Archer, specifically some of the analytical concepts she has developed in "Social origins of educational systems", has stimulated our interest in the tension between regional diversity and national uniformity. Archer has identified educational "unification" as a structure and process that is typically promoted by the state. ${ }^{11}$ Unification has two aspects: intensive and extensive unification. Intensive unification concerns the effectiveness of policy implementation. High intensive unification requires an administrative hierarchy with clear lines of command ensuring the implementation of state policy at the local level. Extensive unification means that state controlled educational arrangements extend to all regions and localities of the nation. ${ }^{12}$ The state tends to pursue a policy of both intensive and extensive unification because it is in the interest of the state to facilitate efficient administration as well as effective policy implementation on a national scale.

The effect of compulsory education laws on enrolment rates is an issue in the

9 Ida Bull and Jakob Maliks, eds., Riket og regionene: Grunnlovens regionale forutsetninger og konsekvenser (Trondheim: Akademika forlag, 2014).

10 Charlotte Appel and Morten Fink-Jensen, Da loereren holdt skole: Tiden før 1780, Dansk skolehistorie, vol. 1 (Aarhus: Aarhus universitetsforlag, 2013).

11 Margaret S. Archer, Social Origins of Educational Systems (London: Routledge, 2013 [1979]), 17476.

12 Archer (2013 [1979]), 200. Here we only consider Archer's concepts intensive and extensive unification. These concepts are part of a comprehensive theory about the emergence and elaboration of state educational systems, which also includes the concepts centralised and decentralised state educational systems. Since different authors define these terms differently, and - according to Archer's definition of the educational system - we are dealing with a period prior to the emergence of the educational system proper, we will not use the concepts centralisation and decentralisation here. 
international literature. ${ }^{13}$ The intention of the legislators who enacted the early 1739 legislation on rural elementary education in Denmark and Norway was to introduce compulsory education for all. However, the authorities provided no central funding for schools. Not until the mid-nineteenth century did Norwegian elementary education received central funding. ${ }^{14}$ Still Norway figures among the Western European countries that at an early stage had high enrolment rates. An investigation of 17 Western European countries placed Norway in a group of countries together with Denmark, Sweden and Prussia. Not only did these countries introduce compulsory education laws at an early date, but they also had early high enrolment rates. In other European countries, either increased enrolment did not follow subsequent to the enactment of national compulsory laws or it happened before the passing of compulsory laws. Yasemin Nuhoglu Soysal and David Strang reporting these results, suggest that the alliance between the national church and the state, which distinguished the group of Nordic countries and Prussia from the rest, enabled the effective coupling of legislation with organisation for enrolment. The church with its well-developed nation-wide organisation was a precondition and a facilitator for the implementation of centrally initiated educational reforms. ${ }^{15}$

Norwegian educational historians have come to a similar conclusion about the vital role of the church in the organisation of early elementary education, highlighting that church personnel at all levels, the local parson as well as the bishops played a central role in the implementation of the eighteenth and early nineteenth century education acts. There was no central funding for the early schools, except in the north of Norway, ${ }^{16}$ but an important sanction that served to enforce enrolment was the 1736 compulsory confirmation act, which established prior schooling and the ability to read as requirements for confirmation in the church. Knut Tveit claims that the confirmation was the driving force behind the implementation of the eighteenth century elementary education acts. The function of the school as preparation for the

13 See Yasemin Nuhoglu Soysal and David Strang, "Construction of the First Mass Education Systems in Nineteenth-Century Europe," Sociology of Education 62 (1998) and Karen Clay, Jeff Lingwall and Melvin Stephens, Jr., "Do Schooling Laws Matter? Evidence from the Introduction of Compulsory Attendance Laws in the United States" (Cambridge, Massachusetts: National Bureau of Economic Research, NBER Working Paper Series, 2012), http://www.nber.org/papers/w18477 (accessed February 1,2016$)$.

14 During the eighteenth century in the northern parts of Norway, Nordland and Troms, the state paid salaries for elementary school teachers from the Mission fund, which the king had established for education and missionary work among the Sami during the early decades of the century. In the 1740 s teachers in eight out of twelve regions in Nordland as well as some of the regions in Troms were paid from the Fund. Knut Tveit, "Skolen i Nord-Noreg på 1700-talet," Skolen: Arbok for norsk utdanningshistorie (2004), 46.

15 Soysal and Strang (1989), 278, 286. Although these authors' data on Norwegian education are incorrect in claiming that compulsory education was introduced in Norway in 1848 and that the rate of enrolment in 1870 was $61 \%$, the ranking of Norway seems right, placing it among the early legislators of compulsory education and with an early high enrolment rate.

16 Central funding of schools in Northern Norway came from the "Mission Fund", which was dedicated to education and missionary work among the Sami population, see Liv Helene Willumsen, "Økonomiske vilkår for lærerutdanning i det nordlige Norge - den historiske utvikling av Seminarii Lapponici Fond», in Norrlandsfrågan: Erfarenheter av utbildning, undervisning och fostran $i$ nationalstatens periferi, edited by David Sjögren and Johannes Westberg (Umeå: Kungl. Skytteanska samfundets handlingar, 2015), footnote 84 . This fund was also used to finance schools for the Norwegian population. See Tveit (2004). 
confirmation made the school acceptable to the local population. ${ }^{17}$ Though the state generally did not fund the first compulsory schools, at the mid-nineteenth century there was a very high enrolment rate in Norwegian elementary education compared to other European countries. ${ }^{18}$

In this article, we will not systematically pursue the effects of introducing compulsory education laws on enrolment. Our focus is on the political intentions behind the post 1814 educational legislation in Norway. We want to explore whether national unification and regional and local diversity were issues in the educational debates in the Norwegian Parliament from 1815 to 1827 . If these issues were salient, we want to ascertain whether national uniformity was preferred to regional differentiation; and finally, we want to find out how the issue of regional diversity and national uniformity was resolved in the 1827 act on rural elementary education. A close reading of the previous eighteenth century educational reforms in Denmark and Norway, enacted under the absolute Monarch Christian VI, and historical research on educational development in Norway following these reforms will be presented as a backdrop to the analysis of the post 1814-education acts and debates.

\section{Previous research on the 1827 rural education act}

In Norway, the educational legislation in 1816 and 1827, which followed the introduction of the constitution in 1814, did not mention education for citizenship at all. Although the Norwegian 1814-constitution did not include any paragraphs on education, Torstein Høverstad, in an early study, pointed out the contradiction between the constitutional principle of popular sovereignty and the strong emphasis on the teaching of religion as well as church control of elementary schools in the $1827 \mathrm{edu}-$ cation act. ${ }^{19}$ Høverstad saw this contradiction to result from the conscious intention of the political elite to maintain barriers to the political participation of the peasants. ${ }^{20}$ More recent historical accounts have described the contradiction between the constitution and the 1827 act as a "delay" in Norwegian educational legislation, claiming that the educational consequences of the constitution were not drawn until the 1860 educational reform: "1814 in [Norwegian] educational history is 1860 ". ${ }^{21}$

The idea of a contradiction between the constitutional principle of popular sovereignty and the 1827 educational reform has, however, been disputed. Erling Lars Dale highlights the limited suffrage granted by the constitution. ${ }^{22}$ Only "independent" citizens who owned property and citizens with higher education had the right to vote. The franchised "people" in the constitution did not include servants, women, land labourers and other groups without education or property. Because of the limited suffrage at the time, elementary education for commoners was not associated

17 Knut Tveit, Allmugeskolen på austlandsbygdene 1730-1830 (Oslo: Universitetsforlaget, 1991), 51.

18 Hans-Jørgen Dokka, Fra almueskole til folkeskole (Oslo: Universitetsforlaget, 1967), 25. In 1837 the enrolment rate in rural areas was $94 \%$ of the relevant age cohorts. In the towns the rate was $84 \%$.

19 Torstein Høverstad, Norsk skulesoga: Det store interregnum 1739-1827 (Kristiania: Steenske Forlag. 1918).

20 Ibid., 366.

21 Alfred Oftedal Telhaug and Odd Asbjørn Mediås, Grunnskolen som nasjonsbygger (Oslo: Abstrakt forlag AS, 2003), 55.

22 Erling Lars Dale, De strategiske pedagoger: Pedagogikkens vitenskapshistorie i Norge (Oslo: Ad Notam Gyldendal, 1999). 
with political participation. ${ }^{23}$ Instead, Dale claims, the authorities considered education for commoners as an aspect of church policy. To substantiate this point, he mentions that in 1821 a complete education act was included in the proposition for a new church law, the "Act on Religion and the Clergy". Written and presented by the minister for church and education, Niels Treschow, this proposition contained altogether 10 paragraphs dedicated to "education for the young". 24 The inclusion of educational legislation in church laws was, however, only a passing moment. The acts of $1739 / 41,1816$ and 1827 were all independent education acts.

Still, the 1827 act clearly placed elementary education under the control of the church. Its curricular content displayed few traces of secular school subjects, which advocates for the enlightenment had suggested as relevant for the peasant population. There was no mention of "citizenship virtues". ${ }^{25}$ The schools" primary aim was to prepare for the confirmation in the church. The final "exam" was the confirmation, which required religious knowledge at a level determined by the local parson. ${ }^{26}$ The Plan and Instructions issued in 1834, underlined the religious ethos of the schools and admonished the teachers to represent Christian morality: "true fear of God and Christian moral conduct". ${ }^{27}$ The teacher should teach the children to distinguish between "Good and evil" and to "understand the fateful consequences of $\sin ^{28}$ Ambulant teachers should also conduct evening prayers in the homes where they stayed, if it was the wish of the household. ${ }^{29}$

One could still argue that the 1827 act's emphasis on the teaching of religion (in addition to reading, writing and arithmetic) expressed a concern for the ideal citizen implied by the constitution, since it defined Norway as a "confessional state", proclaiming, "The religion of the state is the evangelical-Lutheran faith". Thus, in order to be a good citizen one had to be a solid Lutheran. However, this dimension of the ideal citizen was identical with the "ideal subject" of the absolute state and had nothing to do with political participation.

Although Høverstad's pioneering study from 1918 has been criticised by Dale and others, there is agreement on his observation that the final act, passed in 1827, was decidedly more preservative of the status quo in education than its earlier versions. All the sessions in Parliament from 1816 to 1826 had discussed various versions of the act. ${ }^{30}$ Høverstad sees the final act as a combined effect of the pursued self-in-

\footnotetext{
23 Dale (1999), 308.
}

24 The Parliament never voted over this law. In 1821, an overcrowded agenda prevented it. The government did not present it a second time, due to resistance against its suggestions for a stricter church discipline. See Tønnes Sirevåg, Niels Treschow: Skolemann med reformprogram - det frie Norges første kirkestatsråd ved aktstykker opplyst (Oslo: Selskapet for norsk skolehistorie, 1986), 124-33.

25 Skinningsrud and Skjelmo (2014), 31-51.

26 Lov angaaende Almue-Skolevoesenet paa Landet. Stockholms Slot den 14nde Juli 1827, \$15.

27 Plan og Instrux for almueskolen, 1834. \$ 3 www.fagsider.org/kirkehistorie/lover/1834_planoginst. htm (accessed January 29, 2016).

28 Ibid. $\$ 8$.

29 Ibid. $\$ 17$. The ambulant teacher was the typical teacher in rural Norway until the mid-1860s. He stayed with local farmers and taught a group of pupils from the neighbouring farms, moving "his school" every 3-7 days from one farm to the next. In 1837 most Norwegian parishes lacked permanent schools (schoolhouses), $87 \%$ of all pupils in rural areas attended ambulant schools. See Oskar Bandle et al., eds. The Nordic Languages, volume 2 (Berlin: Walter de Gruyter, 2005), 1527.

30 Skinningsrud and Skjelmo (2014). 
terest of the elite, who did not want an educated peasantry, and the neo-pietistic religiosity among the leading peasant members of Parliament, who considered secular school subjects as a threat to religion. Høverstad points to the paradox that the conservatism and the preservation of church control of elementary education embodied in the 1827 act, was the joint effect of rationalism and neo-pietism. The political elite were rationalist in orientation, whilst the neo-pietists, belonging to the Hauge-movement, ${ }^{31}$ were opposed to the enlightenment idea of secular elementary education for commoners. Høverstad claims that the Hauge-movement wanted to safeguard the school from "the false worldly wisdom", which the rationalists and enlightenment thinkers had advocated. ${ }^{32}$ In Høverstad's interpretation these orientations, the self-interest of the rationalist political elite and the neo-pietism of the Hauge-movement, were curiously combined by the leader of the Parliamentarian committee, theology professor Svend Hersleb, who in 1827 presented the proposition to the Parliament, being a member of the elite as well as a sympathiser with the Hauge-movement. ${ }^{33}$

Both of Høverstad's explanatory factors, the self-interest of the political elite and the fear among the Hauge-followers that secular knowledge would threaten religion, have been contested by research that is more recent. Marthe Hommerstad claims that the political elite, the state bureaucrats, were not opposed to education for the peasants. ${ }^{34}$ In addition, research on the Hauge-movement has cast doubts on the premise that it was uniformly opposed to secular knowledge in the schools. Merely the members' entrepreneurialism and business activities, which required considerable knowledge of a non-religious nature, would testify to the contrary.

\section{The 1739 acts on rural education in Denmark and Norway}

The post-1814 legislation built on the legacy of the eighteenth century education acts and the uneven success of their implementation. During the eighteenth century,

31 The Hauge-movement was a lay awakening movement in Norway initiated by Hans Nielsen Hauge (1771-1824). Hauge did not have any formal education, but had experienced a calling from God to become a lay preacher. He travelled all over Norway and attracted a large following. Since he preached outside the church and without any formal theological training, he violated the prohibition of private religious gatherings without the permission of the church's local representative (the 1741 Conventicle Act). Hauge was an active entrepreneur and he, as well as his followers, was successful in business. From 1804 to 1811, he served a prison sentence for his lay preaching and business activities. See Linda Haukland, "Hans Nielsen Hauge," Scandinavian Journal of History 37, no. 5 (2014), 539-59.

32 Høverstad (1918), 366. Historians differ in their assessment of the Hauge-movement's attitude to education. On the one hand, it is a common opinion that the movement greatly contributed to the development of literacy among the peasants and commoners during the nineteenth century because members of the movement studied the bible, discussed the Holy Scripture in Conventicles (private assemblies) and maintained their network by writing letters to each other. The historian Halvdan Koht claims that members of the Hauge-movement were the backbone of the early peasant opposition in the Parliament. On the other hand, Jostein Fet, Lesande bønder (Oslo: Universitetsforlaget, 1995), 196, quotes a contemporary source, the rationalist priest Blichfeldt, who claims that the Hauge-movement condemned all literature that diverted attention from the one and only necessary concern: to obtain eternal life. Fet also quotes the Norwegian linguist and creator of Norway's second official language, New Norwegian, Ivar Aasen, who describes the Hauge-movement as hostile to secular knowledge.

33 Høverstad (1918), 367.

34 Marthe Hommerstad, Politiske bønder: Bondepolitikk og Stortinget 1815-1837 (PhD diss., University of Oslo, 2012). 
Denmark and Norway were in a union, and there was parallel educational legislation for the two countries. The tension between national uniformity and regional differentiation was already present in the 1739-41 acts on rural education in Norway.

The two 1739 acts on rural elementary education enacted by the Danish pietistic king Christian VI, one for Norway (NF) and one for Denmark (DF), prescribed compulsory elementary education in all rural areas. ${ }^{35}$ The parson and the Dean should appoint a local teacher, who was obliged to include all parish children in the school, both rich and poor, without charging fees. The parson and the Dean should also examine the teacher and ensure that "[...] no strange vagabonds, women, former soldiers or lower military officers are used without being examined by the parson." 36 Home tutoring was strongly discouraged, and the parson should admonish the parishioners to "send their children to school and not allow them to receive tutoring at home" ${ }^{37}$ Sources of funding for the schools were similar in the two countries. Each district ( $\operatorname{sog} n)$ should establish a school fund (Kasse), which could consist of private donations, ${ }^{38}$ but a cop tax should supplement the fund. No one in the local area $(\operatorname{sog} n)$ should be exempted from the tax "whether it was the landed estate, the parson's household or the common people, except those who rely on alms alone." 39

In the 1739 acts the regional authorities (stiftsdireksjonen), the bishop and the royal fief-holder (amtmannen), were responsible for assessing the need for schools and the approval of local school plans within the diocese. The Placat of 1740 for Denmark (DP) and of 1741 for Norway (NP), however, seriously modified the 1739 acts and reduced them to ideal standards that the localities might or might not achieve, depending on their capacities and circumstances. The reasons for the modification was that the Danish act had been heavily criticised by the Danish aristocratic landowners (proprieterene), who would have had to bear the major costs connected with the establishment of rural schools. The Danish Placat, which retracted the 1739 act, in its introduction explained that the king, on scrutiny, had realised that the costs of implementing the act would amount to "a considerable sum" as well as "much inconvenience", and that the landowners would have to cover the major part of the costs. The king's reasoning was that the youngsters could acquire the necessary knowledge for the salvation of their souls without placing "too heavy a burden on the owners of the land [...]". Since the landowners were in the best position to know "the capacity of the estates and the conditions of their cultivators", the landowners could themselves suggest "where, and how many schools that were needed on each estate". ${ }^{40}$ In other words, in Denmark, the decision making power to establish schools was left to the landowners and not to the bishop and the royal fief-holder, which had been the prescribed arrangement in the 1739 act.

While the Placat for Denmark made the owners of large estates into the local decision makers of school development, the Placat for Norway placed this responsibility

35 A close reading of the legal text in the two laws, for Denmark and Norway, confirm that they are identical. See Høverstad (1918), 6; Einar Høigård and Herman Ruge, Den norske skoles historie: En oversikt (Oslo: J. W. Cappelens Forlag, 1947), 44; Appel and Fink-Jensen (2013), 193.

$36 \mathrm{DF} \$ 38$; NF $\$ 39$.

$37 \mathrm{DF} \$ 38 ; \mathrm{NF} \$ 39$.

$38 \mathrm{DF} \$ 31 ; \mathrm{NF} \$ 32$.

$39 \mathrm{DF} \S 32 ; \mathrm{NF} \S 33$.

40 Introduction to DP. 
with the "rural congregations, which have the best knowledge of the conditions and situation in the district". ${ }^{41}$ The Dean was responsible for the establishment of a school commission in each of his parishes, which beside the parson and his chaplains, consisted of four among the "best and most knowledgeable men" in the parish, the local sheriff, the local tax collector ( $f \circ g d)$ and local proprietors, if there were any. ${ }^{42}$

In Denmark, on the other hand, the school fund should be administered by the "the largest land owner in the school district", who should "supply the income and pay the expenses, assisted by the fief-holder". ${ }^{43}$ The largest landowners were authorised both to decide the local school tax and the remuneration of the local teacher. "It is the land owner themselves that decide, and distribute the burden among themselves, what the school masters need for their up-keep and, what they in salary and income shall receive, since the king assumes that they treat the school masters in a way which ensures that they do not perform their job moaning". ${ }^{44}$ The resolution of disagreements among the landowners concerning the distribution of expenses should follow the principle: "what the largest land owner decides, the smaller land owners should be content with [...]." If this principle did not solve the dispute, the fief-holder and the Dean should decide on the case, and report their decision to the bishop and the fief-holder who should have the final say. The landowners also had the authority to decide whether and to what extent "they want to reclaim expenses for school buildings and annual teacher remuneration from their peasants and servants." 45

The Placat for Denmark of 1740 left decisions on school development and the funding of schools to the local owners of large estates, while the Placat for Norway of 1741 authorised the fief-holder together with the Dean to establish local school commissions, which would ensure school development and local funding through taxation. This difference in the administration of the schools and their economy corresponds to the general difference, which the Norwegian historian Ståle Dyrvik has noted, between the practice of state governance in Denmark and Norway. ${ }^{46}$ In Denmark, the 700 private landowners were in charge of several economic and administrative state functions in exchange for royal privileges and tax exemptions. "In Norway, on the other hand, a complete local administration was built up, through which the extended arm of the king reached everyone". ${ }^{47}$ Dyrvik's point is that in Norway local state officials ("the extended arm of the king") interacted with the local population on educational issues, while in Denmark, the commoners had to relate to a landowner and his officials. In the Norwegian school commissions, which were responsible for school planning and execution of the plan for the schools' economy and administration, state officials encountered the commoners. ${ }^{48}$

41 Introduction to NP.

42 NP $\$ 2$.

$43 \mathrm{DP} \$ 5$.

44 DP $\$ 5$.

45 DP $\$ 6$.

46 Ståle Dyrvik, Truede tvillingriker 1638-1814: Danmark-Norge 1380-1814, vol 3 (Oslo: Universitetsforlaget, 1998).

47 Ibid., 36.

48 Tone Skinningsrud, Fra reformasjonen til mellomkrigstiden: Framveksten av det norske utdanningssystemet (PhD diss., University of Tromsø, 2013), 263. 
Danish educational historians have described the eighteenth century's difference in Norwegian and Danish educational governance as a difference in democratic popular influence. The Norwegian school commissions, where local farmers often constituted the majority, epitomise the democratic influence. However, Appel and Fink-Jensen point out that also in Denmark, for example among the peasants in West Jutland and on the island Bornholm, the parishioners exerted influence on local school arrangements because there were no large landholders. ${ }^{49}$

\section{Educational development in Norway after the 1739/1741 legislation}

Norwegian educational historians have agreed that the essential consequence of the 1741 Placat's modification of the 1739 act was that "the local communities and the regional state authorities were allowed to implement the act in the way that they wanted and to the extent that they mustered"..$^{0}$ The 1741 Placat for Norway reduced the 1739 act to an ideal standard for the school, and the local school commissions and the regional state authorities were authorised to implement the act to the extent that they found feasible.

The peasants constituted the most powerful group in the school commissions, and it would be impossible to implement decisions about local school taxes without the consent of the peasant population. ${ }^{51}$ Høverstad claims that the local school commission mobilised resistance against the establishment of schools. The commissions were disposed for conflict because the duty of the state officials was to promote the school, while the peasants, who often constituted the majority in the commissions, had to bear the costs. The commissions so to speak produced resistance against establishing schools for the peasants, because the school issue activated an already existing contradiction between the state officials and the peasants. ${ }^{2}$

Høverstad's assessment is that even though there were vast differences between communities in educational provisions, the general state of affairs was stagnation. Helgheim has challenged this view. He has studied the increasing number of schoolteachers in rural areas of Norway during the period 1750 to 1810 as an indicator of the increasing volume of pupils attending schools. ${ }^{53}$ His estimate is that from 1750 to 1780, there was a growth of 43 per cent in teacher positions, and from 1780 to 1810 , the growth was 21 per cent. However, the increase in teacher positions relative to general population growth remained constant. ${ }^{54}$ Helgheim concludes that during the whole period from the 1739/41 education acts to 1814, there had been a considerable increase in educational provisions for the population in rural areas. Growth had been slow, but the overall change was formidable. In principle, the provision of formal education for all, had taken over informal home tutoring of children. The extent to which provisions were available depended on regionally approved plans worked out by the local school commissions. However, the central authorities had played its

49 Appel and Fink-Jensen (2013), 201, 210.

50 Høverstad (1918), 5; Johannes Helgheim, Allmugeskolen paa bygdene (Oslo: Aschehoug \& Co, 1980), 62.

51 Høverstad (1918), 8-9.

52 Ibid., 15.

53 In $1801,91.2 \%$ of the Norwegian population lived in rural areas. Helgheim (1980), 57.

54 Ibid., 58. 
part by issuing reminders and instructions for the development of local plans several times during the latter half of the eighteenth century. ${ }^{55}$

Tveit as well has argued that Høverstad overestimates the peasants' resistance against elementary education during the 1700s. He claims that the impression of intense and extensive conflicts between the peasants and the state officials in the local school commissions is due to a bias in available historical sources, since conflicts tend to produce more documents for public archives than agreement. ${ }^{56}$ Tveit's own research from the eastern part of Norway during the 1700s indicates that from 1775 to 1818 there was a 50 per cent increase in the number of teachers in this part of the country, while the population growth was 30 per cent. ${ }^{57}$ His general impression from studying local school plans in the archives is that the local population generally had a positive attitude towards the school, even though it meant taxation. He attributes this to the fact that education was necessary to pass the confirmation, which was a requirement for obtaining full rights as a citizen: the right to marry, to obtain work and to possess property. ${ }^{58}$

A recent study, which compares a community in the Trondheim region with a community in Kristiansand before and after 1814, presents a more diversified picture of the local school commissions. This study documents that the level of conflict was different in different communities. Differences between the local commissions in terms of size, composition and policy practices, reflecting differences in the social structure of local communities may have caused different levels of conflict. ${ }^{59}$

Despite disputes among historians about the prevalence of local resistance to the establishment of rural elementary schools, and the uncertainties about the volume of schooling, there is general agreement that educational development during the second half of the eighteenth century varied between the regions.

Some authors consider the uneven development as caused by the 1741 Placat because it allowed each community to decide how to extract taxes to cover expenses for the school. ${ }^{60}$ The Placat relinquished the original ambition of the policy makers for a uniform national arrangement for the school ${ }^{61}$ However, local and regional differences were not only due to "flexible local arrangements" allowed by the general legislative framework. The authorities in Copenhagen also differentiated between regions by exempting some from implementing the acts. Already in 1742, the Chancellery exempted the administrative district Nordland and Troms, in Northern Norway, from the 1739 act and the 1741 Placat on advice from the regional fief-holder and the bishop. ${ }^{62}$ The district was not obliged to establish school funds. Instead, each parson would have an assistant for supervising home tutoring done by the parents. The Northern Norway Mission Fund, which was primarily dedicated to educational

55 Ibid., 52-59.

56 Tveit (1991), 205.

57 Ibid., 77. Akershus, the part of Norway examined by Tveit, from 1730 to 1830 , had $42-43 \%$ of the total population in Norway. Ibid., 81.

58 Tveit (2004).

59 Tor Bjerkås, “Grunnloven og lokaloffentligheten,” in Riket og regionene: Grunnlovens regionale forutsetninger og konsekvenser, ed. Ida Bull and J. Maliks (Trondheim: Akademika forlag, 2014), 101, 113.

60 Høigård and Ruge (1947), 46.

61 Helgheim (1980), 35.

62 Ibid., 36; Tveit (2004), 36. 
and missionary work among the Sami, provided the funding for the assistants. ${ }^{63}$ The 1739/41 acts were not implemented in Nordland and Troms until 1778. ${ }^{64}$

Since Medieval Times, the whole of Northern Norway had been included in the Diocese of Trondheim (Nidaros). However, in 1804 the authorities established a separate diocese in Northern Norway, consisting of the present days' counties Nordland, Troms and Finnmark. The first bishop in this northernmost region of Norway, Bonsach Krogh, a philanthropist by conviction, held the post until 1828. However, stormy weather and bad health prevented him from carrying out his visitations. It was also very difficult to get parsons to his diocese. Before 1814, he complained several times per year to the Chancellery in Copenhagen, and after 1814 to the Ministry of Church Affairs in Oslo, of widespread clerical vacancies in Finnmark. In 1824, six posts were vacant in Finnmark and nine in Nordland. Lack of church personnel of course had consequences for school development in the area. The bishop's visitation protocols tell stories about poverty, destitution, and dilapidated school buildings. "The common people very negligent" and "the knowledge among the young extremely lacking" were common descriptions. ${ }^{65}$

Bjerkås claims that at the transition from the eighteenth to the nineteenth century "legal amendments and local adaptations had produced an education sector that was not unified throughout the nation but varied between individual districts" ${ }^{66}$ The regional differences in school development (stift) that existed in Norway at the beginning of the nineteenth century were caused both by the differentiated regional policy conducted by the authorities in Copenhagen and by variations in educational initiatives and efforts among the regions, who worked out local plans for the school in accordance with their local means. ${ }^{67}$

Appel and Fink-Jensen, in their discussion of the 1739/40 educational legislation on elementary education in Danish and Norwegian rural districts, conclude that although these acts represented an attempt by the king to establish uniform elementary education in the two countries, they resulted in putting a stamp on regional and local differences. ${ }^{68}$ Also in Denmark regional differences in schooling arrangements were both a result of variations in local traditions and initiatives and variations in central policy decisions concerning regions. The major achievement of the 1739/41 acts was to signal that universal elementary education was a concern for the state, rather than the levelling of regional and local differences. ${ }^{69}$

\section{General change in Norwegian regional policy after 1814}

Norwegian historians have pointed out that towards the end of the union with Denmark; Norway had ceased to function as a unified realm. ${ }^{70}$ For a long time the king

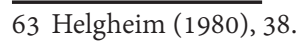

64 Tveit (2004).

65 Høverstad (1918), 257, 261.

66 Bjerkås (2014), 100.

67 Westberg has made the same point about central legislation and local funding being necessary preconditions for educational development in Sweden after the 1842 education act. Westberg (2014), 66.

68 Appel and Fink-Jensen (2013), 216.

69 Ibid., 203-16.

70 Jakob Maliks, “Grunnloven og regionene: Hegemoni, kontinuitet og brudd," Heimen 49 (2012), 15-16; Bugge and Mykland (1987), 234; Maurset (1979), 15, quoted in Maliks (2012). 
and Chancellery in Copenhagen had governed Norway through a direct link to individual regional public officials without going through a national administrative centre. The regions (stift) - that is, the Dioceses, whose borders coincided with those of secular administrative units - were the primary economic, cultural and administrative units. After 1814, however, the functional differentiation of the regions gradually decreased.

During the union between Denmark and Norway central political decision-makers in Copenhagen enacted laws and regulations for both countries. The central decision-makers often differentiated between regions by making decisions that only applied to one region at a time. One single bishop could be the recipient of a rescript. This practice was contrary to a uniform governance of the Norwegian territory. Historians have designated the policy principle underlying this practice the "whole-state-policy" (Helstatspolitikk), which they often explain as a policy of amalgamation and uniformity, with the intent of evening out regional differences. ${ }^{71}$ However, the "whole-state-policy" was not about introducing uniform governance, i.e., common rules and laws for the whole realm. The intention was primarily to strengthen the state. The result of this policy was an increase of regional differentiation rather than more equality between regions. The effect of Norwegian independence from Denmark in 1814 was not only that the political centre moved from Copenhagen to Christiania (Oslo); it also entailed the pursuit of a new state policy that entailed nationally uniform legislation and less differential treatment of the regions.

The question whether the educational legislation for the recently established Norwegian state should be general and have a nation-wide scope or should deal separately with specific regions was a theme in the Norwegian educational debate after 1814. In the first ordinary Parliamentary meeting 1815-16, there were propositions for a new education act that concerned only one region (stift) as well as propositions covering the whole nation..$^{72}$

\section{Legislative work in the Norwegian Parliament 1815 to 1827}

\section{Educational debates 1815-1816}

During the summer session in 1815, the first Parliamentary assembly in Norway had to deal with three different proposals concerning the improvement of elementary education. Two bishops, Christian Sørensen in Christiansand, Frederik Julius Bech in Akershus, and the schoolteacher Thomas O. Amle, who was a member of the Hauge-movement, a religious awakening movement among the laity, ${ }^{73}$ had prepared separate proposals for legislation on elementary education. Bech's proposal was for a national act covering the whole country, while Sørensen's proposal was for a tempo-

71 Jakob Maliks and Ida Bull, "Med regionen som utsiktspunkt," in Riket og regionene: Grunnlovens regionale forutsetninger og konsekvenser, ed. Ida Bull and Jakob Maliks (Trondheim: Akademika forlag, 2014), 14.

72 Betenkning til Odelstinget fra medlemmer av 1ste, 3die, 4de og 6te combinerede Comittee ang. Almueskolevæsenet 28 March 1816. Storthingsforhandlinger 1815 and 1916, 100-23.

73 Amle's membership in the Hauge-movement is mentioned in Olav Golf, Haugebevegelsen og folkeopplysningen (1996) and in Hommerstad (2010), 210. See also note 20 in this article. 
rary two-year reform in his own diocese. Amle also proposed national legislation. ${ }^{74}$ The Parliament appointed a separate committee to consider the three proposals and coordinate them. ${ }^{75}$

Although Amle, being a school teacher, had a more modest social standing than the two bishops, his proposal for ambulant schools for the younger children, until the age of 12, and permanent schools for the older ones, was adopted by the commission. ${ }^{76}$ The committee considered Amle's proposition to be more realistic than the more ambitious proposal from Bech, who had suggested more permanent schools and longer school years. ${ }^{77}$ The result of the committee work was a comprehensive proposition in 35 paragraphs, which concerned permanent schools, ambulant schools and teacher education as well as economic arrangements for the schools, taking into consideration local ways of life. For communities that moved to the mountains with their herds during the summer (seterdrift), the school would close during the summer season. Likewise, the school would close during seasonal rural labour. Also during the periods when the fisheries were intensive, the school would close.

The committee had had a thorough discussion on whether educational legislation should be national or regional. Agreeing on a national act the committee was still aware of the problems associated with national legislation, considering the obstacles created by the Norwegian topography:

[The committee] also acknowledges how overwhelmingly difficult it is to conceive of a law, which can be enforced in a country like Norway, where local conditions, the working life of the people and their economic conditions are so varied, where the relatively sparse population lives spread out on a variegated area, where the communications are made so difficult, here by mountains and long valleys, and there by rivers and fjords $[\ldots]]^{78}$

Although the proposition was the result of extensive deliberations, a vote of 27 against 26 rejected the proposition. Instead, the Parliament on 1 July 1816 decided on a temporary act consisting of only three paragraphs. However, this short temporary act was also a national act. Moreover, contrary to earlier and later education acts, this act covered towns as well as rural districts, though with some difference between arrangements for rural and urban schools.

74 Amle suggested ambulant schools for the smaller children, up until 12 years of age, and permanent schools for the older children. He also suggested the development of teaching materials: a book of readings containing pieces about nature studies, natural history, world history, biographies, also a book for arithmetic exercises and for texts that should be learnt by heart. See Helgheim (1980), 62; Golf (1996), 151.

75 Betenkning til Odelstinget fra medlemmer av 1ste, 3 die, 4 de og 6te combinerede Comittee ang. Almueskolevæsenet 28de March 1816. Storthingsforhandlinger 1815 and 1816, 100-23.

76 The difference between permanent and ambulant schools was that permanent schools required schoolhouses, while ambulant schools entailed the teacher moving between the various farms in his district conducting his lessons in the homes of the farmers.

77 Hommerstad (2012), 210.

78 Storthingsforhandlinger (Mai 1815-1816), 100-4. The population in Norway at this time was around 890,000 . This was close to the size of Denmark's population of 925,000, but the area of Norway was seven times the size of Denmark. See Olav Kolsrud, Maktens korridorer: Regjeringskontorene 1814-1949, Riksantikvarens Skriftserie 12. (Oslo: Universitetsforlaget, 2001), 19. 


\section{The long parliamentary journey towards the 1827 act for rural elementary education}

Since the 1816 act was temporary, the Parliament decided to forward the different proposals to the Law committee, a permanent committee, whose mandate it was to work out a new proposal for a national elementary education act. ${ }^{79}$ The original proposal, containing 35 paragraphs, which had been rejected by a very narrow majority, had been presented as a national act covering all regions, and besides, as a framework act, which provided general national rules that would allow regional variations. The assumption was that the government, upon applications from the various regions, would permit specific local arrangements for particular communities and districts. ${ }^{80}$ After preparations, in 1818, the Law committee presented the bill to the Parliament a second time. The assembly, during this session, postponed the bill, arguing that the economic situation for the country was very difficult. ${ }^{81}$ In the 1821 session, the bill was presented again, but it was postponed once more, due to an overcrowded agenda of educational issues, among others, teacher education and salaries for elementary school teachers. Besides, this session experienced time shortage, since the Swedish king Carl Johan terminated it prematurely. ${ }^{82}$

In the 1824 Parliamentary session, the Dean P. V. Deinboll, a delegate from Finnmark, suggested a vote on the proposal for the education act. Deinboll had been a delegate also in the 1821 session, where he had engaged in educational issues. He was the main force behind the decision to establish the first state institution for teacher education in Norway, located in the north of the country, at Trondenes in Troms. ${ }^{83}$ Deinboll, although originally from Copenhagen had familiarised himself with the local conditions in the North and discovered the possibility of obtaining central funding for education in Northern Norway. He had found out that there was a Northern Norwegian church and education fund, Seminarii Lapponici Fund, dedicated to educate the Sami. The fund had existed since the early eighteenth century mission among the Sami population in the Northern region. ${ }^{84}$

The 1824 Parliamentary debate on the elementary education act was a lengthy process. It lasted from April until the end of June. The conflict centred on whether the act should be a framework law, leaving the details to be elaborated in local school plans and instructions, or whether the law should contain as much details as possible. The original proposal, which the Law committee had presented in 1816, had been for a framework act. However, some members of Parliament wanted to go even further in making the act into a general framework that skipped the specificities. Two members of Parliament, Deinboll and Schultz, who were both clergy, worked out a proposal consisting in 29 paragraphs, where they had removed 11 of the para-

\footnotetext{
79 Helgheim (1980), 70.

80 Høverstad (1918), 268.

81 Helgheim (1980), 70.

82 Ibid., 70.

83 Randi Skjelmo, "Utdanning av lærere for det nordlige Norge før 1826," in Norrlandsfrågan: Erfarenheter av utbildning, undervisning och fostran i nationalstatens periferi, ed. David Sjögren and Johannes Westberg (Umeå: Kungl. Skytteanska samfundets handlingar, 2015), 81-96.

84 Willumsen (2015), 97-116.
} 
graphs in the proposal from the Law committee. ${ }^{85}$ They had removed the rule about the duration of the school day and the school year, but had kept the general rule from the 1739 act about three months of schooling per year. They had removed the rule about compulsory schooling and about the division into two grades and the maximum number of pupils in each grade, rules about bonuses for schoolmasters, about school hygiene and procedures in connection with contagious diseases. They had also changed the rules about local taxation for the funding of the school. ${ }^{86}$

Helgheim claims that the proposal from Deinboll and Schultz was a weaker act for the elementary school than the proposal from the Law committee. He criticises Høverstad for describing it too positively. ${ }^{87}$

The Church and Education committee in the Parliament did not reach an agreement on the elementary education act in the 1824 session, and it suggested sending all documents concerning the case to the government, so that it could arrange a hearing among the clergy and the regional authorities (stiftsdireksjonen). This procedure would help the government in preparing a new proposition. The two proposals, from the Law commission and from Deinboll and Schultz were both printed and circulated in a hearing round. ${ }^{88}$ The proposal from the Law commission contained 40 paragraphs and the proposal from Deinboll and Schultz contained 29 paragraphs.

The Deans and the bishops were obliged to reply to the hearing. For lower clergy it was voluntary, and there were few hearing replies from the parsons. Altogether only 74 members of the clergy (24 per cent) sent their written comments to the ministry. ${ }^{89}$ Helgheim claims that the final proposition, containing 28 paragraphs, which the government presented to the Parliament on February 6th 1927, was a compromise between the proposal from the Law commission and the proposal from Deinboll and Schultz. The proposition was, however, more like a framework act, which had been Deinboll's and Schultz' preferred solution. Many among those who participated in the hearing did not see the difference between the two proposals. ${ }^{90}$ Theology professor Svend Hersleb, who was the leader of the Church and Education committee in the Parliament, authored the committee's resolution about the proposal addressed to the Parliament. Hersleb was a strong supporter of a religious elementary school and an anti-rationalist. ${ }^{91}$ The resolution emphasised that a national act must be a framework act, which allows local variations within the framework of the law:

\footnotetext{
The difficulty consists partly in that it is necessary to take into consideration the locality, and this makes it impossible to formulate other than very general prescriptions, because specific rules will not be applicable everywhere, partly it consists in that the necessary resources for a more adequate elementary school for the commoners is lacking. Likewise, the many received hearing answers from knowledgeable clergy in
}

85 Høverstad (1918), 288.

86 Helgheim (1980), 71. Deinboll had other ideas on how to fund elementary schools in Northern Norway, apart from taxation. Among other things, he suggested in the Parliament in 1821 to add income from whales that drifted ashore to the school fund.

87 Ibid., 76.

88 Ibid., 71.

89 Høverstad (1918), 292.

90 Ibid., 297.

91 Ibid., 293. 
the various regions show how many insurmountable hindrances that will meet the implementation of an act if prescripts could not be modified in accordance with the diverging characteristics of the regions $[\ldots] .^{92}$

The final text of the act provided a concession to regional differences in that $\$ 28$ provides the smaller administrative units, amtsdireksjonen, in the Nordland and Finnmark regions (amt), with the same authority that in other regions of the country were granted to the more encompassing regional units, the stiftamt.

The act "Lov angaaende Almueskole-Væsenet på Landet" received Royal sanction on July 21st by King Carl Johan at Stockholm Castle. It would take another six years before the enactment of "Plan og Instrux", in 1834.

\section{Conclusion}

In this article, we have raised the question whether 1814, the year of the establishment of the Norwegian constitutional state, marked a change in educational policy and legislation, from differential treatment of the regions to a more consistent promotion of national uniformity. Our approach to the post-1814 Norwegian educational legislation differs from previous research among Norwegian educational historians, which has mainly focused on the conservatism of the 1827 act, which did not mention education for citizenship, which one might expect in a new constitutional state. Neither did the act show any traces of enlightenment ideas concerning the spreading of secular knowledge among the common people. We ask the questions: were national unification and regional diversity issues in the educational debates in the Norwegian Parliament from 1814 to 1827 ? Did the politicians prioritise national uniformity before regional differentiation? How was the issue of regional diversity and national uniformity resolved in the 1827 act on rural elementary education?

As a backdrop to our investigation of post-1814 educational debates and legislation we have presented a close reading of the 1739/41 acts on rural elementary education in Denmark and Norway and presented earlier research on the state of affairs in Norwegian education during the latter half of the eighteenth century. The Danish and Norwegian eighteenth century acts differed in local arrangements for decision-making on educational development. In the major parts of Denmark, the large landowners were responsible for presenting local plans for establishing schools, while in Norway; the local school commissions, where peasants constituted the majority, were responsible for the development of local plans. In both countries during the latter half of the eighteenth century, educational development was uneven among regions. Uneven development, partly caused by differences in central decision-making for various regions and partly caused by difference in local initiatives and circumstances, was the legacy for Norwegian rural elementary education when the Norwegian state started to work on its new educational legislation.

Legal proposals and debates during the early years after 1814 confirm that regional and national acts were alternatives for the legislators. At the first Parliamentary assembly in 1815, proposals for new legislation on elementary education consisted of both regional and national acts. The Parliament decided in favour of a national act. The issue concerning regional variation and national uniformity, continued to

92 Storthingsforhandlinger (May 1827), 180-81, ref. in Helgheim (1980), 78. 
figure in the debates until the final passing of the 1827 elementary education act. The difficulties created by variations in local topography and economic circumstances for the implementation national uniformity, and how to created possibilities for local and regional adaptations resulted in the adoption in 1827 of a framework act, which allowed local adaptations to some extent.

\section{Acknowledgement}

The authors are grateful to Daniel Tröhler for comments on an earlier version of this article. 


\section{References}

\section{Education Acts}

Anordning for Almueskolevoesenet paa Landet i Danmark, 29 July 1814. http://danmarkshistorien.dk/leksikon-og-kilder/vis/materiale/anordning-for-almueskolevaesenet-paa-landet-i-danmark-af-29-juli-1814/?no_cache $=1 \& \mathrm{cHash}=\mathrm{c}-$ 99e9c365ddbb176d9050d9ce49ff54d (accessed February 14, 2016).

Forordning om Skolerne på Landet i Danmark og Hvad Degnene og Skoleholderne derfor må nyde (DF), January 23, 1739. http://danmarkshistorien.dk/leksikonog-kilder/vis/materiale/forordning-om-skolerne-paa-landet-i-danmark-1739/ (accessed July 12014 ).

Forordning om Skolerne paa Landet i Norge, Og Hvad Klokkerne og Skoleholderne derfor maa nyde (NF), January 23, 1739. http://www.fagsider.org/kirkehistorie/ lover/1739_skole.htm (accessed July 1, 2014).

Lov, angaaende Almue-Skolevasenet paa Landet, July 14, 1827. http://www.fagsider. org/kirkehistorie/lover/1827_skole.htm (accessed July 1, 2014).

Plan og instruks for almueskolen 1834. www.fagsider.org/kirkehistorie/lover/1834_ planoginst.htm (accessed July 1, 2014).

Placat og Normere Anordning ang. Skolerne paa Landet i Danmark (DP), April 29, 1740. http://danmarkshistorie.dk/leksikon-og-kilder/vis/materiale/placat-angskolerne-paa-landet-i-danmark-1740/ (accessed July 1, 2014).

Placat og Noermere Anordning Angaaende Skolerne paa Landet i Norge (NP), May 5, 1741. http://www.fagsider.org/kirkehistorie/lover/1741_placat.htm (accessed July 1, 2014).

\section{Other sources and literature}

Appel, Charlotte, and Morten Fink-Jensen. Da leereren holdt skole: Tiden før 1780. Dansk skolehistorie Vol. 1, Hverdag, vilkår og visioner gennem 500 år, edited by C. Appel and N. de Coninck-Smith. Aarhus: Aarhus Universitetsforlag, 2013.

Archer, Margaret Scotford. Social Origins of Educational Systems. London: Routledge, 2013 [1979].

Bandle, Oskar, Kurt Brannmuller, Ernst Håkon Jahr, Alan Karker, Hans-Peter Nauman, eds. The Nordic Languages, volume 2. Berlin: Walter de Gruyter, 2005.

Bjerkås, Tor. "Grunnloven og lokaloffentligheten." In Riket og regionene: Grunnlovens regionale forutsetninger og konsekvenser, edited by Ida Bull and Jakob Maliks. Trondheim: Akademika forlag, 2014.

Bull, Ida, and Jakob Maliks, eds. Riket og regionene: Grunnlovens regionale forutsetninger og konsekvenser. Trondheim: Akademika forlag, 2014.

Clay, Karen, Jeff Lingwall, and Melvin Stephens, Jr., "Do Schooling Laws Matter? Evidence from the Introduction of Compulsory Attance Laws in the United States. Cambridge." Massachusetts: National Bureau of Economic Research, NBER Working Paper Series, 2012. http://www.nber.org/papers/w18477 (accessed February 1, 2016).

Dale, Erling Lars. De strategiske pedagoger: Pedagogikkens vitenskapshistorie i Norge. Oslo: Ad Notam Gyldendal, 1999.

Dokka, Hans-Jørgen. Fra almueskole til folkeskole. Oslo: Universitetsforlaget, 1967, Dyrvik, Ståle. Truede tvillingriker 1648-1720: Danmark-Norge 1380-1814. Bind III. Oslo: Universitetsforlaget, 1998. 
Fet, Jostein. Lesande bønder: Litteræer kultur i norske allmugesamfunn før 1840. Oslo: Universitetsforlaget, 1995.

Golf, Olav. Haugebevegelsen og Folkeopplysningen 1800-1860. Rapport nr. 6. Pedagogisk forskningsinstitutt, Universitetet i Oslo, 1996.

Haukland, Linda. "Hans Nielsen Hauge." Scandinavian Journal of History 37, no 5 (2014), 539-559.

Helgheim, Johannes. Allmugeskolen paa bygdene. Oslo: Aschehoug \& Co., 1980.

Hobsbawm, Eric. The Age of Revolution 1789-1848. 1st Vintage Books Ed. New York: Random House. 1996 [1962].

Hommerstad, Marthe. Politiske bønder: Bondepolitikk og Stortinget 1815-1837. PhD diss., University of Oslo, Faculty of the Humanities, IAKH, 2012.

Høigård, Einar, and Herman Ruge. Den norske skoles historie: En oversikt. Oslo: J. W. Cappelens Forlag, 1947.

Høverstad, Torstein. Norsk skulesoga: Det store interregnum 1739-1827. Kristiania: Steenske Forlag, 1918.

Ihalainen, Pasi, Michael Bregnsbo, and Karin Sennefelt, eds. Scandinavia in the Age of Revolutions: Nordic Political Cultures 1789-1848. Farnham: Ashgate Publishing Groups, 2011.

Kolsrud, Olav. Maktens korridorer: Regjeringskontorene 1814-1949, Riksantikvarens Skriftserie 12. Oslo: Universitetsforlaget, 2001.

Larsen, Christian, Erik Nørr, and Pernille Sonne. Da skolen tog form 1780-1850. Dansk skolehistorie, Vol. 2, Hverdag, vilkår og visioner gennem 500 år, edited by C. Appel and N. de Coninck-Smith. Aarhus: Aarhus Universitetsforlag, 2013.

Maliks, Jakob, and Ida Bull. "Med regionen som utsiktspunkt." In Riket og regionene: Grunnlovens regionale forutsetninger og konsekvenser, edited by Ida Bull and Jakob Maliks. Trondheim: Akademika forlag, 2014.

Maliks, Jakob. “Grunnloven og regionene: Hegemoni, kontinuitet og brudd." Heimen 49 (2012).

Palmer, Robert R. The Age of Democratic Revolution: A Political History of Europe and America 1760-1800, Vol. 1. Princeton: Princeton University Press, 1959.

Paksuniemi, Merja. "Udvikling af det finske folkeskolevæsen fra 1860'erne til 1920'erne." Uddannelseshistorie 48 (2014).

Sirevåg, Tønnes. Niels Treschow: Skolemann med reformprogram - det frie Norges første kirkestatsråd ved aktstykker opplyst. Oslo: Selskapet for norsk skolehistorie, 1986.

Skinningsrud, Tone. Fra reformasjonen til mellomkrigstiden. Framveksten av det norske utdanningssystemet. PhD diss., University of Tromsø, 2013.

Skinningsrud, Tone, and Randi Skjelmo. "Fra enevelde til konstitusjonell stat. Forutsetninger for allmueskolelovgivning i Norge etter 1814." Uddannelseshistorie 48 (2014).

Skjelmo, Randi. "Utdanning av lærere for det nordlige Norge før 1826." In Norrlandsfrågan: Erfarenheter av utbildning, undervisning och fostran i nationalstatens periferi, edited by David Sjögren and Johannes Westberg. Umeå: Kungl. Skytteanska samfundets handlingar, 2015.

Soysal, Yasemin Nuhoglu and David Strang. "Construction of the First Mass Education System in Nineteenth-century Europe." Sociology of Education 62 (1989).

Storthingsforhandlinger 1815 og 1816. Christiania 1817 and 1818. 
Telhaug, Alfred Oftedal, and Odd Asbjørn Mediås. Grunnskolen som nasjonsbygger. Oslo: Abstrakt forlag AS, 2003.

Tröhler, Daniel. "Curriculum History". In The Oxford Handbook for the History of Education. 2016 (in press).

Tveit, Knut. Allmugeskolen på austlandsbygdene 1730-1830. Oslo: Universitetsforlaget, 1991.

Tveit, Knut. "Skolen i Nord-Noreg på 1700-talet." In Skolen: Årbok for norsk utdanningshistorie, 2004.

Tveit, Knut. "Formålsparagrafen - eit 150-årig uroelement." Kirke og Kultur 2 (2007).

Westberg, Johannes. "En politisk illusion? 1842 års folkskolestadga och den svenska folkskolan." Uddannelseshistorie 48 (2014).

Willumsen, Liv Helene. "Økonomiske vilkår for lærerutdanning i det nordlige Norge - den historiske utvikling av Seminarii Lapponici Fond." In Norrlandsfrågan: Erfarenheter av utbildning, undervisning och fostran i nationalstatens periferi, edited by David Sjögren and Johannes Westberg. Umeå: Kungl. Skytteanska samfundets handlingar, 2015. 